KOŚCIÓŁ I PRAWO 10(23) 2021, nr 1, s. 89-105

DOI: http://dx.doi.org/10.18290/kip21101-6

\author{
Bartosz Trojanowski
}

\title{
KATOLIK JAKO ŚWIADEK SAKRAMENTU CHRZTU ŚW.
}

\begin{abstract}
WSTĘP
W obowiązującym Kodeksie Prawa Kanonicznego z 1983 r. ${ }^{1}$ chrzestnym poświęcone są trzy kanony, które stanowią oddzielny rozdział w tytule dotyczącym sakramentu chrztu (kan. 872-874). O świadku sakramentu chrztu traktuje tylko jeden paragraf jednego ze wspomnianych kanonów (stanowiąc o możliwości bycia świadkiem przez niekatolika), a także kan. 875 wymagający obecności świadka, jeśli nie ma chrzestnego. I chociaż nie ma nawet osobnego tytułu w KPK/83 poświęconego świadkom chrztu, to jednak fakt istnienia takiej funkcji i jej rolę przy udzielaniu tego sakramentu podkreślają niektóre inne przepisy dotyczące chociażby stwierdzenia samego faktu chrztu. Dlatego też warto zastanowić się nad znaczeniem tej osoby pełniącej takie zadanie oraz nad możliwością wypełniania go przez katolika, jak też nad okolicznościami, które przemawiałyby za takim rozwiązaniem. Rozważania tego artykułu mogą przysłużyć się do usunięcia pojawiających się niejednokrotnie błędów lub wątpliwości w tej materii w praktyce duszpasterskiej.
\end{abstract}

Ks. DR BARTOSz TROJANOWSKI - Kuria Metropolitalna Wrocławska; adres do korespondencji: Pl. Katedralny 14, 50-329 Wrocław, Polska; e-mail: b.trojanowski@hadak.pl; https://orcid.org/0000-0003-0158-1647

${ }^{1}$ Codex Iuris Canonici auctoritate Ioannis Pauli PP. II promulgatus (25.01.1983), AAS 75 (1983), pars II, s. 1-317; tekst polski: Kodeks Prawa Kanonicznego, przekład polski zatwierdzony przez Konferencję Episkopatu, Pallottinum, Poznań 1984 [dalej cyt.: KPK/83]. 


\section{CHRZESTNY A ŚWIADEK SAKRAMENTU CHRZTU ŚW.}

Ustawodawca powszechny stawia wymaganie, że „przyjmujący chrzest powinien mieć, jeśli to możliwe, chrzestnego. Ma on dorosłemu towarzyszyć w chrześcijańskim wtajemniczeniu, a dziecko wraz z rodzicami przedstawiać do chrztu oraz pomagać, żeby ochrzczony prowadził życie chrześcijańskie odpowiadające przyjętemu sakramentowi i wypełniał wiernie złączone z nim obowiązki” (kan. 872 KPK/83).

\subsection{Obowiązek posiadania chrzestnego}

W kan. $872 \mathrm{KPK} / 83$ przedstawiona jest zasada generalna, zgodnie z którą przyjmujący chrzest powinien mieć chrzestnego. W języku kanonicznym, podobnie jak w języku prawnym szerzej rozumianym, przez słowo „powinien” zawiera się obowiązek, który należy wypełnić. Jednakże do tej normy nakładającej obowiązek posiadania chrzestnego przez kandydata do chrztu jest przypisana klauzula warunkująca, ,jeśli to możliwe”, a zatem ustawodawca przewiduje takie sytuacje w wyjątkowych okolicznościach, kiedy nie będzie możliwe wyznaczenie chrzestnych, a jednocześnie będzie możliwe udzielenie tego sakramentu. A zatem, aby nie pozbawić dobra duchowego kandydata do chrztu, należy mieć na uwadze fakt, że obowiązek posiadania chrzestnego nie jest warunkiem sine qua non, a przez to nie należy $\mathrm{w}$ pewnych sytuacjach domagać się wyznaczenia rodzica chrzestnego, który nie jest w stanie wypełniać takiego zadania. Brak chrzestnego nie stanowi przeszkody do udzielenia sakramentu, ponieważ nie stanowi warunku do ważności tego sakramentu, nie tylko w sytuacjach niebezpieczeństwa śmierci czy „przypadkach naglącej konieczności” (kan. $850 \mathrm{KPK} / 83$ ), ale w każdym przypadku nie wpływa na ważność tego sakramentu. Należy zatem podkreślić, że na podstawie kan. 872 brak chrzestnego z uzasadnionej przyczyny nie może pozbawić kandydata do chrztu św. prawa do tego sakramentu (por. kan. 206, 213, $843 \S 1 \mathrm{KPK} / 83$ ).

Już od starożytności chrześcijańskiej istniała figura chrzestnych w liturgii sakramentu chrztu św. oraz życiu chrześcijańskim. O zobowiązaniach chrzestnego wspomina Tertulian w Traktacie o chrzcie św. z przeł. 
II i III w. ${ }^{2}$ Prawdopodobnie rola chrzestnych wzięła się z praktycznych powodów, a mianowicie od początków Kościoła, kiedy wiarę katolicką chciał przyjąć poganin lub Żyd, wówczas byli oni przedstawiani prezbiterowi przez znanego chrześcijanina, który zaświadczał o jego odpowiedniej dyspozycji do przyjęcia sakramentu chrztu św., to szczególnie nabierało znaczenia w okresie prześladowań [Blanco 2004a, 479]. O roli chrześcijanina jako adductor lub fidedictor wspominają także starożytne źródła chrześcijańskie ${ }^{3}$.

Zadaniem stawianym przed chrzestnym w KPK/83 jest generalnie określając „obowiązek ich udziału we wtajemniczeniu chrześcijańskim osoby chrzczonej oraz pomoc, jaką powinni jej później okazywać, aby żyła zgodnie z otrzymanym chrześcijańskim powołaniem" [Majer 2011, 670]. Ustawodawca rozróżnił zadania chrzestnego na dwa przypadki: wobec dorosłego oraz wobec dziecka [Blanco 2004a, 480]. W przypadku dorosłego, chrzestny „ma towarzyszyć w chrześcijańskim wtajemniczeniu”, co Wprowadzenie ogólne do Wtajemniczenia chrześcijańskiego wyjaśnia jako pomaganie chrześniakowi przynajmniej w ostatnich przygotowaniach do przyjęcia sakramentu, natomiast po chrzcie dbać o to, by chrześniak wytrwał w wierze i w życiu chrześcijańskim ${ }^{4}$. Kiedy przyjmującym chrzest jest dziecko, wtedy chrzestny powinien wraz $\mathrm{z}$ rodzicami przedstawić je, jest on wtedy przedstawicielem „zarówno rodziny ochrzczonego, rozszerzonej w znaczeniu duchowym, jak i Kościoła, naszej Matki” (OCWD 8). Zadaniem jest troszczyć się o to, aby ochrzczony prowadził życie chrześcijańskie odpowiadające przyjętemu sakramentowi i wypełniał wiernie złączone z nim obo-

${ }^{2}$ Tertullian, De baptismo, (XVIII,4), w: Tertullien. 1952. Traité du baptême, Sources Chrétiennes, Paryż: CERF, 92.

${ }^{3}$ Tradycja apostolska: „Kiedy zostaną wyznaczeni mający zamiar przyjąć chrzest, należy sprawdzić ich życie: czy żyli godnie dopóki byli katechumenami, czy poważali wdowy, nawiedzali chorych, czynili dobre uczynki. Kiedy ci, którzy ich przyprowadzili zaświadczą o każdym: «On postępował właśnie tak», to niech słuchają Ewangelii”. Zob. Hipolit Rzymski, Tradycja Apostolska, w: H. Paprocki, Hipolita Rzymskiego Tradycja Apostolska. Wstęp, przekład komentarz, „Studia Theologica Varsoviensia” 14 (1976), nr 1, s. 158. Konstytucje Apostolskie: „[Dopuszczenie do katechumenatu] Tych, którzy po raz pierwszy przystępują do tajemnicy pobożności, diakoni powinni przedstawić biskupowi lub prezbiterom; kandydatów należy zapytać, dlaczego chcą przyłączyć się do Słowa Pańskiego; ci zaś, którzy ich wprowadzają, powinni poręczyć za nich po uprzednim dokładnym ich sprawdzeniu [...]”. Zob. Konstytucje Apostolskie, red. A. Baron, H. Pietras, Wydawnictwo WAM, Kraków 2007.

${ }^{4}$ Obrzędy Chrześcijańskiego Wtajemniczenia Dorostych. Dostosowane do zwyczajów diecezji polskich, Księgarnia św. Jacka, Katowice 2016 [dalej cyt.: OCWD], nr 8. 
wiązki, w przypadku dziecka to zadanie będzie przede wszystkim polegało na wspieraniu rodziców w staraniu o to, by dziecko doszło do wyznania wiary i wyrażało ją życiem (OCWD 8).

W przypadku, kiedy kandydatem do chrztu św. jest osoba dorosła, Wprowadzenie ogólne stwierdza, że „zgodnie ze starodawnym zwyczajem Kościoła człowiek dorosły nie może być dopuszczony do chrztu bez chrzestnego, wybranego ze wspólnoty chrześcijańskiej” (OCWD 8). Ten warunek wydaje się być w sprzeczności z kan. $872 \mathrm{KPK} / 83$, który jednak dopuszcza wyjątki, używając formuły ,jeśli to możliwe”. W historii Kościoła „profil” chrzestnego miał różny walor prawny, z pewnością większy w stosunku do obecnego, zawartego w KPK/83 [Pighin 2016, 117]. W związku z tym należy pamiętać, że ustawodawca w kan. $2 \mathrm{KPK} / 83$ stwierdza, iż „obowiązujące dotychczas przepisy liturgiczne zachowują swoją moc, chyba że któreś z nich są przeciwne kanonom Kodeksu”, chociaż Kodeks nie określa „zazwyczaj” przepisów, jakie należy zachowywać przy sprawowaniu czynności liturgicznych, to jednak może stanowić warunki, które zezwalają na przyjęcie sakramentu lub odmowę udzielenia go. Należy podkreślić, że kan. $872 \mathrm{KPK} / 83$ jest taką normą. Jednakże formuła w nim zawarta otwiera możliwość na wyjątki. Takiej możliwości wydaje się nie pozostawiać $\mathrm{nr} 8$ Wprowadzenia ogólnego, chociaż czytając tę normę w kontekście innych należy stwierdzić, że nie uwzględnia ona $\mathrm{np}$. kwestii niebezpieczeństwa śmierci, w której warunki te nie są wymagane (OCWD 16). Podsumowując, trzeba zauważyć, że wiążącym jest tutaj przepis zawarty w KPK/83, który wymaga chrzestnego w przypadku dorosłego, jednakże w sytuacjach, w których nie jest to możliwe, dopuszcza udzielenie tego sakramentu również bez niego. Należy podkreślić, że istnienie klauzuli ,jeśli to możliwe” w kan. 872 KPK/83 osłabia obowiązkowość tej normy, która ma charakter „napominający”, a jednocześnie pozwala stwierdzać, że prawodawca powszechny uwzględnił, że są dopuszczalne takie przypadki, w których jest niemożliwe posiadanie chrzestnego. To jednak nie powinno stawać się normą [Montan 2004, 82].

O powinności posiadania chrzestnych stanowi także ustawodawca w kan. $873 \mathrm{KPK} / 83$. Jednakże jego akcent jest troszeczkę inny, chodzi bowiem o stwierdzenie, że może być tylko jeden chrzestny lub chrzestna i to jest wystarczające. Natomiast, jeżeli wybiera się dwoje chrzestnych, to należy wybrać ich tak, aby był jeden ojciec chrzestny i jedna matka chrzestna. Wyraźnie to podkreśla tekst łaciński stwierdzając: unus et una, a w tłuma- 
czeniu na język polski użyto liczebnika zbiorowego „dwoje”, który zakłada różnicę płci dwóch osób zawartych w danej grupie. Dlatego należy stwierdzić, iż treść tego kanonu jeszcze bardziej podkreśla, iż figura chrzestnego jest bardzo istotna i należy dołożyć wszelkich starań, aby przynajmniej zapewnić jednego chrzestnego - jeśli tylko jest to możliwe.

\subsection{Wymagania stawiane chrzestnym}

Ze względu na obowiązki wielkiej wagi, jakie stawiane są przed chrzestnymi, aby móc pełnić taką rolę należy wypełnić szereg wymagań stawianych przez prawodawcę, a zawartych w kan. 874 KPK/83. Należy zauważyć, że pierwszym $\mathrm{z}$ warunków jest prawo do tego zadania nadane przez kandydata do chrztu lub w przypadku dziecka przez jego rodziców lub prawnych opiekunów oraz intencja podjęcia się tego zadania przez chrzestnego (kan. 874, $1^{\circ} \mathrm{KPK} / 83$ ), dlatego prawodawca postawił granicę ukończenia 16 lat, aby móc pełnić te zadania, jednak możliwe są wyjątki ustanowione przez prawo partykularne ze względu na słuszną przyczynę (kan. $874,2^{\circ}$ ). Ponadto ustawodawca kodeksowy wymaga, aby chrzestny był katolikiem, bierzmowanym i przyjął już sakrament Najświętszej Eucharystii oraz aby prowadził życie zgodne $\mathrm{z}$ wiarą i odpowiadające funkcji, którą ma pełnić (kan. 874, $3^{\circ}$ ). Chrzestny musi być wolny od kary kanonicznej (kan. $874,4^{\circ}$ ) oraz nie może to być ojciec ani matka przyjmującego chrzest (kan. $874,5^{\circ}$ ).

Należy stwierdzić, że wszystkie warunki są do godziwości, zgodnie z kan. $10 \mathrm{KPK} / 83$, ponieważ nie została zawarta wyraźna wola ustawodawcy do określenia ich jako warunków do ważności. W Kodeksie Prawa Kanonicznego z 1917 r. ${ }^{5}$ istniał podział między warunkami podanymi w kan. 765, a warunkami do godziwości podanymi w kan. 766. Taką formę w pierwszej kolejności również przyjęto przy formułowaniu obowiązującego kan. 874, jednakże podczas pracy nad treścią tego kanonu zrezygnowano z ustalenia, iż warunki te są do ważności przyjęcia tego zadania ${ }^{6}$. Taka praktyka rozróżnienia warunków co do ważności i godziwości została

\footnotetext{
${ }^{5}$ Codex Iuris Canonici Pii X Pontificis Maximi iussu digestus Benedicti Papae XV auctoritate promulgatus (27.05.1917), AAS 9 (1917), pars II, s. 1-593.

${ }^{6}$ Por. „Communicationes” 13 (1981), s. 229-31.
} 
zachowana w Kodeksie Kanonów Kościołów Wschodnich ${ }^{7}$, te pierwsze podane w kan. $685 \S 1$, a w $§ 2$ tego kanonu do godziwości [Frank 2012, 72]. Warto zauważyć, że ustawodawca w motu proprio De concordia inter Codices $^{8}$ nie ujednolicił tej różnicy między kodeksami. Rozstrzygając tę kwestię należałoby stwierdzić, że chociaż eksperci pracujący przy tej normie prawnej zrezygnowali z klauzuli do ważności, to jednak trzeba zauważyć, że trudno jest pełnić właściwie tak ważną funkcję, jeśli nie spełnia się warunków, które wymaga prawodawca. Dlatego warunki te należy traktować łącznie i nie dyspensować kandydatów na chrzestnych z żadnego $\mathrm{z}$ nich, jeśli nie dopuszcza tego prawo.

\section{PODSTAWY PRAWNE DOTYCZĄCE ŚWIADKA CHRZTU}

\section{1. Świadek niekatolicki a możliwość niekatolickiego chrzestnego}

Po raz pierwszy o świadku chrztu jest wzmianka w kan. $874 \S 2$ KPK/83 i to w dodatku chodzi o ochrzczonego, należącego do niekatolickiej wspólnoty kościelnej. Może on być dopuszczony do takiego zadania tylko razem $\mathrm{z}$ chrzestnym katolikiem. Ustawodawca $\mathrm{w}$ tej normie wyraźnie zaznacza, że chodzi o ochrzczonego we wspólnocie kościelnej niekatolickiej, a zatem można byłoby interpretować ten zapis, iż chodzi o wszystkie wspólnoty niekatolickie, łącznie z tymi Kościołami wschodnimi, które nie zachowują jedności z Kościołem katolickim. I wydaje się słuszne przypuszczenie, że często tak była rozumiana ta norma9. Jednakże uważna lektura kanonów 844 oraz 874 §, a w szczególności terminów w nich zawartych,

${ }^{7}$ Codex Canonum Ecclesiarum Orientalium auctoritate Ioannis Pauli PP. II promulgatus (18.10.1990), AAS 82 (1990), s. 1045-363; tekst polski: Kodeks Kanonów Kościołów Wschodnich promulgowany przez papieża Jana Pawła II, tłum. L. Adamowicz, M. Dyjakowska, Wydawnictwo Archidiecezji Lubelskiej Gaudium, Lublin 2002 [dalej cyt.: KKKW].

${ }^{8}$ Franciscus PP., Litterae apostolicae motu proprio datae quibus nonnullae normae Codicis Iuris Canonici immutantur De concordia inter Codices (31.05.2016), AAS 108 (2016), s. 602-606.

${ }^{9}$ Wiele komentarzy do KPK/83 przypisuje wprowadzenie możliwości bycia chrzestnym przez niekatolików Kościołów wschodnich dopiero poprzez promulgację Dyrektorium ekumenicznego z 1993 r. W ten sposób uznając ten dokument jako podstawę prawną do takiej możliwości. 
pozwala na stwierdzenie, że w kan. $874 \S 2$ chodzi tylko o członków niekatolickich wspólnot eklezjalnych. Chodzi o terminy „Kościół” (łac. Ecclesia) i „wspólnota kościelna (eklezjalna)” (łac. communitas ecclesialis). Terminy te wyjaśniła Kongregacja Nauki Wiary w deklaracji Dominus Iesus ${ }^{10}$ : „Kościoły (Ecclesiae), które nie będąc w pełnej wspólnocie z Kościołem katolickim, pozostają jednak z nim zjednoczone bardzo ścisłymi więzami, jak sukcesja apostolska i ważna Eucharystia, są prawdziwymi Kościołami partykularnymi. Dlatego także w tych Kościołach jest obecny i działa Kościół Chrystusowy, chociaż brak im pełnej komunii z Kościołem katolickim, jako że nie uznają katolickiej nauki o prymacie, który Biskup Rzymu posiada obiektywnie z ustanowienia Bożego i sprawuje nad całym Kościołem. Natomiast wspólnoty kościelne (communitates ecclesiales), które nie zachowały prawomocnego Episkopatu oraz właściwej i całkowitej rzeczywistości eucharystycznego misterium, nie są Kościołami w ścisłym sensie; jednak ochrzczeni w tych Wspólnotach są przez chrzest wszczepieni w Chrystusa i dlatego są w pewnej wspólnocie, choć niedoskonałej, z Kościołem” (nr 17).

Już wcześniej takiego rozróżnienia dokonał ustawodawca w KPK/83 (kan. 844, kan. 874 § 2). W kan. $874 \S 2$ wspomina jedynie o niekatolickich wspólnotach kościelnych, a nie o Kościołach, które nie zachowują pełnej jedności z Kościołem katolickim. Jednakże brak wyraźnego stwierdzenia o możliwości bycia chrzestnym wraz $\mathrm{z}$ drugim chrzestnym katolikiem przez osobę prawosławną można uznać za pewnego rodzaju niedopowiedzenie prawne, jeśli nie lukę prawną, która powodowała wątpliwości w interpretacji prawa. W takim przypadku, zgodnie z kan. $17 \mathrm{KPK} / 83$ należy odwołać się do mens legislatoris, a w tym przypadku za źródło takiej informacji o zamyśle ustawodawcy można uznać rozwój tej normy prawnej oraz od 1990 r. - także KKKW. Komisja odpowiedzialna za przygotowanie tego kanonu w dyskusji wyjaśniła, że według dyrektorium ekumenicznego, a dokładniej pierwszej części z 1967 r. ${ }^{11}$, jest taka możliwość, aby chrześcijanie wschodnich obrządków niekatolickich byli chrzestnymi razem z katolikami, co jednak nie zostało zawarte w treści kanonu. Komisja

\footnotetext{
${ }^{10}$ Congregatio pro Doctrina Fidei, Kongregacja Nauki Wiary, De Iesu Christi atque Ecclesiae unicitate et universalitate salvifica (06.08.2000), AAS 92 (2000), s. 742-65; tekst polski w: http://www.vatican.va/roman_curia/congregations/cfaith/documents /rc _con_cfaith_doc_20000806_dominus-iesus_pl.html [dostęp: 04.01.2021].

${ }^{11}$ Secretariatus ad Christianorum Unitatem Fovendam, Directorium ad ea quae a Concilio Vaticano Secundo de re oecumenica promulgata sunt exsequenda (14.05.1967), AAS 59 (1967), s. 574-92, nr 48.
} 
bowiem stwierdziła, że w Kodeksie Prawa Kanonicznego dla Kościoła łacińskiego nie jest konieczne wyraźne określenie tej kwestii ${ }^{12}$. Regulacja taka pojawiła się w kan. 685 § 3 KKKW, w którym ustawodawca wyraźnie dopuścił taką możliwość, aby chrzestnym był akatolik z Kościołów wschodnich, jednak wraz z chrzestnym katolikiem. Dlatego dobrze się stało, że te wątpliwości interpretacyjne rozwiało dyrektorium ekumeniczne z 1993 r., w którym oprócz powtórzenia normy kanonicznej jest także wyjaśnienie kwestii osób prawosławnych: „ze względu na ścisłą komunię istniejącą między Kościołem katolickim i wschodnimi Kościołami prawosławnymi, wolno dla słusznych powodów dopuścić wiernego wschodniego do pełnienia roli chrzestnego katolickiego (lub matki chrzestnej katolickiej) w chrzcie dziecka lub dorosłego katolika pod warunkiem jednak wystarczającego zabezpieczenia edukacji ochrzczonego oraz wiedzy o tym, że dany chrzestny nadaje się do tej roli"13. Prawosławny musi również spełniać takie warunki, jak katolik do bycia chrzestnym, a zatem musi być godny tego zadania [Ghirlanda 2014, 364]. Jednakże należy jasno stwierdzić, że dyrektorium nie zmienia przepisu prawnego zawartego w kan. $874 \S 2 \mathrm{KPK} / 83$, a jedynie jest jego wyjaśnieniem wprowadzającym rozróżnienie pomiędzy niekatolikami wschodnich Kościołów prawosławnych a niekatolikami należącymi do wspólnot kościelnych niemających łączności z Kościołem katolickim, ponieważ zgodnie $\mathrm{z}$ kan. $33 \mathrm{KPK} / 83$ dyrektorium nie mogłoby wprowadzić normy przeciwnej do obowiązującej ustawy. Rozróżnienie to jednak pozwala nabrać pewności, że we wspomnianym kanonie chodzi tylko o niekatolików ze wspólnot eklezjalnych, a zatem można stwierdzić, że o chrześcijanach wschodnich Kościołów prawosławnych ta norma nie traktuje. Stąd też dyrektorium, a nie motu proprio, było wystarczającym dokumentem, aby wprowadzić obowiązującą podstawę prawną, na którą należy powoływać się w przypadku dopuszczenia do zadania chrzestnego osoby wyznania prawosławnego w Kościele obrządku łacińskiego; oczywiście w odniesieniu do kan. $874 \S 2 \mathrm{KPK} / 83$ jako podstawy prawnej, której dotyczy wyjaśnienie zawarte w dyrektorium.

\footnotetext{
12 „Communicationes” 15 (1981), s. 203-204.

${ }^{13}$ Pontificium Consilium ad Unitatem Christianorum Fovendam, Directorium oecumenicum noviter compositum (25.03.1993), AAS 85 (1993), s. 1039-119; tekst polski w: Ut unum. Dokumenty Kościoła katolickiego na temat ekumenizmu 1982-1998, red. S.C. Napiórkowski, Towarzystwo Naukowe KUL, Lublin 2000, nr 98.
} 


\subsection{Troska o obecność świadka podczas chrztu}

W sytuacji, w której nie ma chrzestnego udzielający chrztu powinien zatroszczyć się, aby był przynajmniej jeden świadek, który mógłby stwierdzić udzielenie tego sakramentu (kan. $875 \mathrm{KPK} / 83$ ). Taki wymóg jest podyktowany faktem, iż sakrament chrztu św. nie tylko stanowi ryt sakramentalny, przez który ochrzczony otrzymuje łaskę, ale także sakrament ten niesie ze sobą bardzo ważne efekty prawne w porządku kanonicznym [Chiappetta 2011, 118]. Przede wszystkim z tego powodu wymagany jest choćby świadek chrztu. Z reguły zadanie zaświadczenia o przyjętym chrzcie św. wypełniają chrzestni, którzy są zwyczajnie i z mocy prawa pierwszymi świadkami tego sakramentu. Treść tego kanonu nie podaje przyczyn braku chrzestnych, a jedynie warunek. Chociaż w wielu komentarzach zakłada się, że chodzi o sytuację naglącej konieczności, a może nawet jedynie sytuację chrztu w niebezpieczeństwie śmierci [Beal, Coriden, i Green 2000, 1064], to jednak nie jest to jedyna możliwość występowania świadka przy sakramencie chrztu św., o czym stanowi ustawodawca w kan. $874 \S 2 \mathrm{KPK} / 83$. Generalnie można stwierdzić, że kan. 875 zakłada brak chrzestnych, a przez to zaleca, aby zatroszczyć się o obecność świadka. Należy to zalecenie nałożone na udzielającego chrztu traktować jako środek ostrożności, który ma na celu możliwość udowodnienia udzielenia sakramentu. Regulacja KPK/83 (łac. curet ut, chociaż w języku polskim przetłumaczone na „powinien zatroszczyć się”, w języku prawnym mogłoby być odczytane jako obowiązek) zakłada, że nie jest to nawet obowiązek co do godziwości, jest to swoistego rodzaju środek, który ma za zadanie pomóc w przyszłości w ewentualnej konieczności udowodnienia faktu chrztu przez świadectwo wiarygodnej osoby, jednakże ze względu na istnienie innych możliwości udowodnienia, np. poprzez metrykę chrztu lub inne sposoby potwierdzające udzielenie tego sakramentu (oświadczenie dorosłego kandydata do chrztu lub przedstawienie nagrania jako dokumentu, oświadczenie szafarza chrztu) powoduje, że obecność świadka przy chrzcie, gdzie nie ma chrzestnych, nie jest warunkiem ani do ważności, ani nawet do godziwości [Blanco 2004b, 482-83]. 


\section{ZADANIE ŚWIADKA CHRZTU ŚW.}

Ustawodawca w KPK/83 stanowi: „do udowodnienia chrztu, jeśli to nie przynosi nikomu szkody, wystarczy oświadczenie jednego wiarygodnego świadka" (kan. 876). Stąd też należy podkreślić, że głównym zadaniem świadka jest gotowość do zaświadczenia, że chrzest odbył się i podanie, w jakich okolicznościach. Należy zatem stwierdzić, że z tego zadania wynikają konkretne obowiązki podczas celebrowania sakramentu, jak również po sakramencie. Ten podział jest podobny do obowiązków chrzestnych, chociaż zakres obowiązków świadków nie jest tak szeroki, a przez to nie mają oni takiej odpowiedzialności jak chrzestni.

\subsection{Obowiązki przy celebracji sakramentu chrztu św.}

Jeśli chodzi o obowiązki przy celebracji sakramentu chrztu św. to należy stwierdzić, że rytuały nie przewidują żadnego zadania dla świadków chrztu. Nie są oni uwzględnieni, jak chrzestni. Należy też wyraźnie stwierdzić, że jeśli nie ma chrzestnych, to świadkowie nie zastępują ich, a zatem nie podejmują dialogu w miejsce rodziców chrzestnych. Przepisy liturgiczne tego nie przewidują, a zatem nie można tego wprowadzać do obrzędu tego sakramentu.

Brak w rytuale sakramentu chrztu św. wzmianki o świadkach nie oznacza, że nie mają oni swoich obowiązków podczas tej celebracji. Należy te obowiązki wyprowadzić pośrednio z przepisów prawa kanonicznego dotyczących świadków. Jeżeli głównym zadaniem świadka jest w razie konieczności potwierdzenie faktu udzielenia chrztu, to pierwszym obowiązkiem świadka jest jego obecność podczas całego obrzędu, a przynajmniej podczas tych czynności, które są niezbędne do ważności tego sakramentu. Przez analogię do świadectwa procesowego można stwierdzić, że od świadka wymaga się, aby jego możliwość potwierdzenia faktu była oparta „na podstawie własnej wiedzy zwłaszcza $\mathrm{z}$ osobistego widzenia i słyszenia” (kan. 1572, $2^{\circ} \mathrm{KPK} / 83$ ), a w związku z tym należy zatroszczyć się, aby świadek znajdował się w takiej odległości, aby mógł widzieć i słyszeć cały obrzęd sakramentu, a przynajmniej tę część, która wymagana jest do jego ważności. Zadanie świadka chrztu można zatem porównać do tego zadania, które ma świadek przy zawieraniu małżeństwa kanonicznego [Redazione di Quaderni di Diritto Ecclesiale 2009, 741]. W konsekwencji świadek 
powinien być $\mathrm{w}$ stanie potwierdzić materię sakramentu chrztu, a mianowicie, że szafarz tego sakramentu użył prawdziwej wody oraz potwierdzić formę sakramentu, czyli to, że szafarz zastosował konieczną formułę słowną (kan. $850 \mathrm{KPK} / 83$ ).

\subsection{Obowiązki po sakramencie chrztu św.}

Nie chodzi tutaj o takie obowiązki, jakie mają rodzice chrzestni, a mianowicie troska, aby „ochrzczony prowadził życie chrześcijańskie odpowiadające przyjętemu sakramentowi i wypełniał wiernie złączone z nim obowiązki" (kan. $872 \mathrm{KPK} / 83$ ). Tego nie wymaga się od świadków, gdyż nie jest to ich zadaniem. Przez obowiązki po chrzcie św. wobec świadka należy określić gotowość do zaświadczenia o jego fakcie udzielenia sakramentu chrztu św., którego był naocznym świadkiem. Ustawodawca w kan. 877 § 1 KPK/83 nakazuje proboszczowi miejsca zapisanie udzielonego chrztu „bezzwłocznie” czyniąc odpowiednie wzmianki, w tym między innymi o „chrzestnych oraz o świadkach, jeśli występują". Określenie to potwierdza rozważane możliwości, a mianowicie obecność rodziców chrzestnych, jednego tylko chrzestnego, jednego chrzestnego i jednego świadka chrztu (niekatolika ze wspólnoty eklezjalnej), przynajmniej jednego świadka chrztu (gdy nie ma chrzestnych).

Ze względu na to główne zadanie świadka, a mianowicie gotowość do zaświadczenia o fakcie przyjęcia chrztu św. przez inną osobą, aby taka możliwość mogła się zrealizować w przyszłości należałoby oprócz danych świadka, czyli imienia i nazwiska zapisać adres zamieszkania lub inną przesłankę, która ułatwi w przyszłości kontakt z daną osobą. Stąd też należy brać pod uwagę, aby na świadków brać osoby, które mają ustabilizowany styl życia i nie wydaje się, że w przyszłości kontakt z nimi będzie utrudniony. Szczególnie chodzi tutaj o szafarza sakramentu, który powinien roztropnie dobrać świadka, jeśli sprzyjają ku temu okoliczności, ponieważ o tym świadku powinien dokonać stosownej adnotacji, a także w przypadku konieczności zaświadczenia należy stwierdzić, że to właśnie szafarz może być tym, od którego będzie domagało się podania danych świadka lub pomoc w ustaleniu sposobu kontaktu ze świadkiem. Trzeba wśród tych różnych przypadków brać pod uwagę również te, które zakładają brak czy to samej adnotacji w księgach metrykalnych, czy też brak 
tejże księgi z zapisem sakramentu chrztu (np. ze względu na zniszczenie w pożarze).

\section{MOŻLIWOŚĆ WYZNACZENIA KATOLICKIEGO ŚWIADKA CHRZTU ŚW.}

Ustawodawca w KPK/83 przewidując zadanie świadka chrztu św. nie zawarł zbyt wielu przepisów dotyczących tego zadania. Ponadto brak jest regulacji jednoznacznie określającej przymioty osoby, która mogłaby je pełnić. Możliwość pełnienia takiego zadania mają chrześcijanie ze wspólnot kościelnych, które nie mają pełnej jedności z Kościołem katolickim. Stąd też czasami pojawia się niezrozumienie dla samej funkcji świadka chrztu, a przede wszystkim możliwości wyznaczenia również katolika do tego zadania. Skoro podstawowym zadaniem jest zaświadczenie o przyjęciu przez jakąś osobę sakramentu chrztu św., to należy rozważyć, jakie osoby mogą pełnić to zadanie i w jakich sytuacjach.

\subsection{Sytuacje wyznaczenia}

Zgodnie z KPK/83 możliwe są sytuacje, w których nie będzie przy sakramencie chrztu św. nawet jednego chrzestnego. Na podstawie klauzuli „jeśli to możliwe” (kan. 872) można wnioskować, że ustawodawca powszechny dopuszcza taką możliwość w różnych przypadkach. W konsekwencji, jeśli nie ma chrzestnych należy zatroszczyć się, aby był przynajmniej jeden świadek (kan. $875 \mathrm{KPK} / 83$ ). Należy podkreślić, że ustawodawca również w sytuacjach, które mogą się w tym kontekście pojawić, nie określił jedynie jako „przypadku naglącej konieczności” (kan. 850), ale dopuścił również inne sytuacje, w których może nie być chrzestnych, np. brak odpowiednich kandydatów. Istotnie praktyka duszpasterska pokazuje, że w ostatnich latach dla niektórych rodziców wydaje się bardzo trudne znalezienie odpowiednich kandydatów na rodziców chrzestnych, którzy spełnialiby wymagania określone w kan. $874 \S 1$. Warunki postanowione wobec chrzestnych w istocie odbierają możliwość pełnienia tego zadania wielu osobom. Może zatem pojawić się sytuacja, w której rodzice nie będą w stanie znaleźć nawet jednego chrzestnego, który spełniłby takie wymagania. 
W takich sytuacjach należy podkreślić, że ustawodawca nie postawił warunku posiadania chrzestnego jako koniecznego do przyjęcia chrztu. A zatem w przypadku, kiedy nie można wyznaczyć nawet jednego chrzestnego dopuszcza się świadka chrztu. Co istotne, to na udzielającym sakramentu spoczywa troska o to, by taki świadek był obecny podczas jego celebracji. Nie jest to również warunek niezbędny, ale jednak w przyszłości może się okazać, że obecność świadka była bardzo pomocna. Nie oznacza to, że rodzice nie mogą podać świadka chrztu, jednak ocena jego wiarygodności i zdolności do podjęcia się tego zadania spoczywa na szafarzu sakramentu, ponieważ to on jest tym, który ma się zatroszczyć o wiarygodnego świadka.

\subsection{Warunki wyznaczenia}

Do udowodnienia chrztu wystarczy „oświadczenie przynajmniej jednego wiarygodnego świadka" (kan. $876 \mathrm{KPK} / 83$ ). Należy stwierdzić, że ustawodawca nie wymaga, aby był to świadek „zakwalifikowany” wcześniej, tzn. ten zapisany $\mathrm{w}$ księdze metrykalnej, a przez to wybrany przez szafarza sakramentu. Jednak taka osoba ma pierwszeństwo w dawaniu świadectwa, ponieważ jej obecność przy zaistniałym fakcie udzielenia sakramentu jest udokumentowana $\mathrm{w}$ księgach metrykalnych. $\mathrm{Z}$ tej normy należy wyprowadzić warunek do wyznaczania świadków chrztu przez szafarza sakramentu, chodzi o to, by brał ten fakt pod uwagę, ażeby osoby, które wyznacza do roli świadka, posiadały wymaganą wiarygodność.

Wspomniano już, że świadek powinien być naoczny, a przez to widzieć i słyszeć, tak, by nie tylko mógł potwierdzić obecność i wydarzenie, ale także zaświadczyć o ważności danego sakramentu przez potwierdzenie użycia odpowiedniej materii i formuły sakramentalnej. Można zatem domniemać, że przez określenie „wiarygodny świadek” należałoby również uznać, że jest to osoba świadoma tego, co jest niezbędne do ważności sakramentu chrztu, nawet w sytuacji niebezpieczeństwa śmierci czy „przypadku naglącej konieczności” (kan. $850 \mathrm{KPK} / 83$ ).

W ustawodawstwie partykularnym mogą pojawić się regulacje dotyczące chrztu św. w przypadkach nieregularnych. Czasami bywa tak, że przy tej okazji podkreślane są również przymioty stawiane wobec chrzestnych. Niekiedy w tym kontekście pojawiają się również stwierdzenia dotyczące świadków chrztu. Wydaje się słuszne uwarunkowanie, że ten katolik, 
który nie może być chrzestnym, nie może również pełnić roli świadka chrztu $^{14}$. Taki warunek ma swoje uzasadnienie zarówno liturgiczne, jak i pastoralne. Świadek chrztu nie ma innych zadań po chrzcie św., jak tylko zaświadczyć o zaistnieniu faktu chrztu, a zatem można byłoby stwierdzić, że jeśli ktoś nie spełnia wymagań na chrzestnego, to może być świadkiem chrztu. W konsekwencji tego można byłoby dopuszczać katolików, którzy nie mogą zostać chrzestnymi, do pełnienia zadania świadka chrztu. W rzeczywistości oznaczałoby to, że świadek stoi obok chrzestnego, chociaż bez uczestniczenia $\mathrm{w}$ dialogu $\mathrm{z}$ rodzicem chrzestnym. Jednak z punktu widzenia duszpasterskiego jest to bardzo niepożądana praktyka, ponieważ daje poczucie danej osobie pewnego substytutu zadań chrzestnego. Może też wprowadzać w błąd wspólnotę Kościoła albo być powodem zgorszenia dla jakiejś grupy wiernych. Dlatego stwierdzenie, że świadkiem nie może być katolik, który nie spełnia warunków na chrzestnego wydaje się być uzasadnione, chociaż nie jest to norma, która wypływa z prawodawstwa powszechnego. Nie jest to jednak norma ogólna, która zakazuje wszystkim katolikom pełnienie tej funkcji.

Pozostaje zatem stwierdzenie, że katolik może być świadkiem chrztu. Uwzględniając jednak fakt, że jeżeli w prawie partykularnym jest taka norma, która zakazuje wyznaczania na świadków chrztu tych katolików, którzy nie mogą być chrzestnymi, to w konsekwencji pozostają tacy katolicy, którzy spełniają takie warunki, jednak z różnych przyczyn nie chcą być chrzestnymi lub nie mogą podjąć się tego zadania, świadomi wielkiej odpowiedzialności wypływającej z jego przyjęcia. Dlatego w przypadku braku chrzestnych sugerować należałoby praktykę wyznaczenia świadka chrztu w osobie katolika o sprawdzonej wiarygodności, który w danej parafii jest znany i dotarcie do niego $\mathrm{w}$ razie konieczności zaświadczenia o udzielonym chrztu będzie możliwe.

\section{3. Świadek katolicki a świadek niekatolicki}

W KPK/83 znajduje się możliwość dopuszczenia chrześcijanina należącego do niekatolickiej wspólnoty kościelnej jako świadka chrztu (kan. 874 $\S 2$ ). Zakłada się zatem, że taką propozycję przedstawia sam kandydat do

\footnotetext{
${ }^{14}$ Arcybiskup Metropolita Wrocławski, Instrukcja $w$ sprawie chrztu dzieci, których rodzice nie sq zwiazani kanonicznym małżeństwem (05.09.2013), „Wrocławskie Wiadomości Kościelne” 66 (2013), nr 2, s. 77-79.
} 
chrztu, a w przypadku dzieci jego rodzice lub prawni opiekunowie. Szafarz chrztu jedynie może dopuścić takiego niekatolika do wypełnienia zadania świadka chrztu. W kan. $875 \mathrm{KPK} / 83$ mowa już jest o świadku, o którego powinien zatroszczyć się szafarz chrztu. Jednak nie wyklucza to możliwości prezentacji kandydata na świadka przez samego przyjmującego chrzest lub jego rodziców bądź opiekunów. Należy zadać pytanie, czy istnieje jakaś różnica $\mathrm{w}$ tych przepisach prawa dotycząca świadka chrztu niekatolika a świadka chrztu katolika? W związku z tym, że ustawodawca nie określił ich zadań, ani nie przewidział rozróżnienia pomiędzy jednym a drugim (poza różnicą wyznania), to w myśl zasady Ubi lex non distinguit, nec nos distinguere debemus zadanie świadka podczas chrztu i po chrzcie jest to samo dla katolika i niekatolika, a mianowicie uczestniczyć w obrzędzie chrztu św. po to, by móc później - w razie konieczności - zaświadczyć o zaistniałym fakcie udzielenia tego sakramentu. Jedynie stwierdzenie, że kan. $874 \S 2 \mathrm{KPK} / 83$ zakłada wyznaczenia świadka przez rodziców, a kan. $875 \mathrm{KPK} / 83$ nakazuje troskę o świadka szafarzowi, nie wydaje się wystarczającą przesłanką do tego, by odróżnić świadka chrztu niekatolika od katolika.

\section{ZAKOŃCZENIE}

Chociaż zadanie świadka chrztu św. nie jest bardzo często spotykane w duszpasterstwie, to jednak należy uwzględnić istnienie takiej funkcji w prawie kanonicznym. Nie tylko w przypadku osób należących do wspólnot kościelnych niekatolickich, kiedy wraz z chrzestnym katolikiem staje przy rodzicach, ale także w przypadku katolików. Prawo kanoniczne przewiduje bowiem przypadki, kiedy nie jest możliwe wykazanie otrzymania sakramentu chrztu św. na podstawie certyfikatu chrztu, a wtedy pierwszym sposobem jest oświadczenie wiarygodnego świadka. Warto zatem mieć świadomość, że w przypadkach przedstawionych w powyższym artykule należy zatroszczyć się o świadka chrztu, gdyż w późniejszym czasie jego oświadczenie może być niezbędne do tego, aby potwierdzić przyjęcie sakramentu chrztu. Możliwość wyznaczenia świadka chrztu podkreśla również fakt, że - zgodnie z wiekową tradycją Kościoła - obecność chrzestnych podczas sakramentu chrztu św., a także w dalszym życiu ich chrześniaka jest bardzo pożądana, to jednak nie stanowi warunku sine qua non, 
ponieważ dobro duchowe kandydata do chrztu św. jest najważniejsze, a zatem brak chrzestnego nie może pozbawić we wszystkich sytuacjach prawa do tego sakramentu.

\section{PIŚMIENNICTWO}

Beal John, James Coriden, i Thomas Green, red. 2000. New Commentary on the Code of Canon Law. New York/Mahwah: Paulist Press.

Blanco, Maria. 2004a. „Can. 872.” W Exegetical commentary on the Code of Canon Law, t. III/1, red. Ernest Caparros, i in., 478-81. Chicago: Wilson \& Lafleur. Midwest Theological Forum.

Blanco, Maria. 2004b. „Can. 875.” W Exegetical commentary on the Code of Canon Law, t. III/1, red. Ernest Caparros, i in., 482-83. Chicago: Wilson \& Lafleur. Midwest Theological Forum.

Chiappetta, Luigi. 2011. Il Codice di Diritto Canonico. Commento giuridico-pastorale. T. 2. Wyd. 3. Bologna: Dehoniane.

Frank, Elias. 2012. I Sacramenti dell'Iniziazione, della Penitenza e dell'Unzione degli infermi. Roma: Urbaniana University Press.

Ghirlanda, Gianfranco. 2014. Il diritto nella Chiesa mistero di comunione. Compendio di diritto ecclesiale. Wyd. 5. Roma: Gregorian \& Biblical Press.

Majer, Piotr, red. 2011. Codex Iuris Canonici. Kodeks Prawa Kanonicznego. Komentarz. Powszechne i partykularne ustawodawstwo Kościoła katolickiego. Podstawowe akty polskiego prawa wyznaniowego. Edycja polska na podstawie wydania hiszpańskiego. Kraków: Wolters Kluwer Polska.

Montan, Agostino. 2004. „I sacramenti dell'iniziazione cristiana.” W Il diritto nel mistero della Chiesa. T. 3: La funzione di santificare della Chiesa. I beni temrporali. Le sanzioni. I processi. Chiesa e comunità politica, red. Gruppo Italiano Docenti di Diritto Canonico, wyd. 3, 63-116. Roma: Lateran University Press.

Pighin, Bruno F. 2016. Diritto sacramentale canonico. Venezia: Marcianum Press.

Redazione di Quaderni di Diritto Ecclesiale, red. 2009. Codice di Diritto Canonico Commentato. Wyd. 3. Milano: Ancora.

Katolik jako świadek sakramentu chrztu św.

\section{Streszczenie}

Podczas udzielania sakramentu chrztu św. Kościół wymaga obecności przynajmniej jednego chrzestnego. Jednak $\mathrm{w}$ pewnych sytuacjach może nie być takiej możliwości, dlatego wtedy należy zatroszczyć się o przynajmniej jednego wiarygodnego świadka. Takim świadkiem może być nie tylko niekatolik ze wspólnoty kościelnej niekatolickiej, ale również katolik, który nie będzie pełnił zadania chrzestnego. Obecność takiego świadka może okazać się bardzo potrzebna w pó́niejszym czasie tak, aby można było 
udowodnić fakt przyjęcia sakramentu chrztu św., gdy będzie taka konieczność. Jednakże zarówno brak chrzestnego, jak i brak świadka chrztu, nie może stanowić przeszkody do udzielenia tego sakramentu.

Słowa kluczowe: sakrament chrztu; chrzestny; świadek chrztu; zadania świadka chrztu; wyznaczenie świadka

\section{Catholic as a Witness of the Sacrament of Baptism}

\section{Summary}

During the administration of baptism, the Church requires that at least one godparent/sponsor be present. However, in some cases this may not be possible, so at least one credible witness should act in their place. Such a witness can a non-Catholic from a non-Catholic church community but also a Catholic who will not formally act as a godfather. The presence of such a witness may prove necessary at a later time when there is a need to testify that the baptised actually received the sacrament. However, both the absence of a godfather and a witness are not obstacles to the administration of the sacrament.

Keywords: the sacrament of baptism; godfather/sponsor; witness of the baptism; tasks of witness of the baptism; designation of witness

Information about Author: Rev. Dr. BARTosz TrojanowsKi - Wrocław Metropolitan Curia; correspondence address: Pl. Katedralny 14, 50-329 Wrocław, Poland; e-mail: b.trojanowski@hadak.pl; https://orcid.org/0000-0003-0158-1647 